\title{
SEISMIC DESIGN OF PALLET RACKING SYSTEMS
}

\author{
B.J. Brown*
}

This paper was presented at the Third South Pacific Regional

Conference on Earthquake Engineering, Wellington, May 1983

SYNOPSIS:

Modern industrial pallet racking systems in use in

New Zealand are adaptions of overseas design, using thin

walled cold formed sections. These sections are not generally

considered suitable for plastic deformations, or resistance to

seismically induced loadings. This paper reviews full scale

shaking table tests reported by Rack Manufacturers Institute, Pittsburg, (R.M.I.) in 1980, and comments on the applicability of the results to the seismic design philosophy embodied in

NZS 4203. Seismic performance criteria (not strictly the same as for building structures) are proposed, and design approaches suggested that will enable the capacity design requirements of NZS 4203 to be considered, while keeping with the cold formed sections traditionally used for pallet rack construction.

\section{INTRODUCTION:}

The use of industrial steel storage racks, or pallet racks, in New zealand has increased over past years, in line with the importation of overseas materials handling technology.

Pallet rack structures are normally supplied pre-fabricated in modular units from cold rolled steel sections which allow maximum user freedom to alter storage patterns within the rack systems many times in its operating life. To achieve this, cold formed column sections are perforated to permit the "clipping-in" of beam ends, or rail brackets, at varying levels. The advantages of cold rolled steel in this application, apart from first cost, is its relative light weight which facilitates demounting without use of lifting plant.

Typical installations in New zealand include bulk warehousing, and bulk cool and cold storage for meat, dairy produce and fruit e.g. kiwifruit. Pallet loads are normally $1000 \mathrm{kilograms}$ and are handled by mobile forklifts whose design is specifically matched to the rack system. Maximum rack heights are presently in the 6 to 9 metre range, with two or three elevated levels of pallets. If overseas trends follow in New Zealand, storage heights will increase and the use of racking systems for bulk storage and distribution of goods will expand.

Under existing New Zealand law, pallet racks come into the category of a "Building", and require structural assessment for permit purposes including seismic loading.

\section{TRADITIONAI APPROACH TO SEISMIC DESIGN OF RACK STRUCTURES:}

Most proprietary pallet rack systems currently available in New Zealand have been developed from overseas design, in which earthquake resistance is not an important design consideration. Codes

* Associate, Murray-North Partners Ltd, Consulting Engineers, Auckland. of practice for structural designs, testing and use of rack structures have been developed in both U.S.A., and U.K./ Europe by the respective Rack Manufacturing Associations. The more important of these are the U.S. (R.M.I.) Specification (Ref. 1) and the U.K. Storage Equipment Manufacturers Association (S.E.M.A.) code (Ref. 2). Only the R.M.I. code makes significant reference to seismic design requirements (based on testing carried out in 1973-74) but does not require any special consideration of post yield behaviour.

In line with the tradition of mechanical plant contracts, the rack manufacturer in New Zealand assumes responsibility for design, as part of the supply and installation package. Since the introduction of NZS 4203 Loadings Code (Ref. 3) in 1976, specifiers and approving authorities have increasingly required specific seismic design of racks in terms of this standard. The traditional design solution has been to superimpose yielding elements in grade 250 steel e.g. tension bracing, on the standard gravity frame system. This approach has raised the questions with regard to:

- The relatively high level of seismically induced acceleration and increased probability of spillage of palletised goods in moderate earthquakes with stiffer rack structures;

- The unproven performance of perforated thin walled cold rolled steel sections when subjected to repeated high strains, particularly in low temperature $\left(-20^{\circ} \mathrm{C}\right)$ applications which encourage brittle fracture in steels. (These sections typically do not satisfy the dimensional limitations required for plastic deformations or required by the plastic, or strength design methods permitted in the materials codes).

- Requirement to install racks in existing buildings, or new buildings without adequate provision for base anchorage of bracing, in those buildings and with limitations specified on permissable uplift in slabs. (Special foundations are not normally provided in buildings 
for rack structures).

- Means of incorporating capacity design principles in demountable structures such as pallet racks.

- Little reported experience of pallet rack performance in earthquakes.

In considering this requirement, extensive reference will be made to two distinct types of rack, which incorporate the main lateral force resisting mechanisms. used by all systems, and the discussion of seismic performance in this paper will be limited to these two rack types:

(i) Standard Pallet Rack

The Standard Pallet Rack is a modular assembly of upright lattice frames, with posts 0.9 to 1.2 metres apart, providing stability in transverse direction. These frames are connected between posts by horizontal "clip-in" beams ( 2.5 to 3.0 metres long) at $1.5 \mathrm{~m}$ centres which provide a semi-rigid joint at the post/column connection.

Longitudinal stability is provided by frame action (through the semirigid joint) or through a supplementary brace or frame system. Loaded pallets within the rack are supported directly by beams under the front and rear of each pallet, with two pallet widths per bay. A schematic arrangement for this rack type is given in Figure 1.

(ii) Drive-In Pallet Racks

The Drive-In rack is an assembly of upright lattice frames in line, providing stability in the transverse direction. These frames are spaced one pallet width apart in the longitudinal direction, to permit fork hoist access to full depth of the rack. Pallets are supported at successive levels (typically 1.8 to 2.4 metres) within the aisles on continuous rails, which are attached by "clip-in" brackets to the lattice frame posts. Bolted row spacers, with semi-rigid connections to the posts, separate adjacent upright frames and provide continuity in the transverse direction. In the longitudinal direction, frames are stabilised at the top by anchor beams and/or a braced diaphragm which transfer the top level reactions from face loading on the upright frames back to the supplementary brace of framing system along the rear wall of the rack. A schematic diagram of a three level multi-bay drive in rack arrangement is given in Figure 6 .

In both standard and drive in systems, column and brace sections are typically fabricated from cold formed lipped channel sections. Floor connection is by anchor bolts through welded baseplates to the posts of the upright frame.
3

\section{SEISMIC STUDY BY RACK MANUFACTURERS INSTITUTE (R.M.I.) 1980}

In June 1980, R.M.I. and U.S. National Science Foundation published results (Ref. 4) of a testing programme on full scale rack assemblies and components carried out by U.R.S./John A. Blume and Associates of San Francisco. The stated objective of this study was to develop realistic seismic design criteria and procedures for rack structures and formulate mathematical models suitable for predicting earthquake response based on the sub-assembly and full scale tests. The project considered standard Pallet Racks, Drive In Racks and Stacker Racks (a hybrid drive in type not considered further in this paper) under the following categories:

(a) Sub-Assembly Tests:

For determination of MomentRotation $(M / \theta)$ relationships from beam to upright connections, derived using the portal frame or cantilever test method.

(b) Merchandise Tests:

To estimate the diaphragm action available from loaded pallets on the racks, and to assess the tendency for loads to spill under earthquake excitation.

\section{Full Scale Tests of Loaded Racks:}

Loaded racks were subjected to simulated earthquake motions using the shaking table facility at Berkeley. Input table motions were scaled from 1940 El Centro NS, and 1966 Parkfield Records, applied in each of the two principal directions of the rack.

\section{Mathematical Modelling:}

To formulate parameters to enable prediction of base shear co-efficients, and fundamental periods for comparison with equivalent lateral force levels. such as those predicted by the ATC-3 method (Ref. 5).

\section{Full details of the experimental} method, analysis and results are given in Ref. 4. Significant results are summarised below:

\section{Sub-Assembly Tests}

The monotonic $M-\theta$ relationship for semi-rigid beam to upright joints are nonlinear, with an initial stiffness range of 500 to $1000 \mathrm{kp}-$ in/rad (56 to $112 \mathrm{kN}-\mathrm{m} / \mathrm{rad}$ ) from the cantilever method of test and about twice this value from the portal method. The ultimate strength of the connection under monotonic loading was determined by tearing in the perforations or deformation in the connection, rather than yield or instability in the beam section itself.

A typical $M-\theta$ curve is shown in Fig. 2 (a).

In the one cyclic load test included (see Fig. 2(b)), stiffness degradation is evident, reportedly associated with cracking between the beam section and the clip-in connector which failed at 


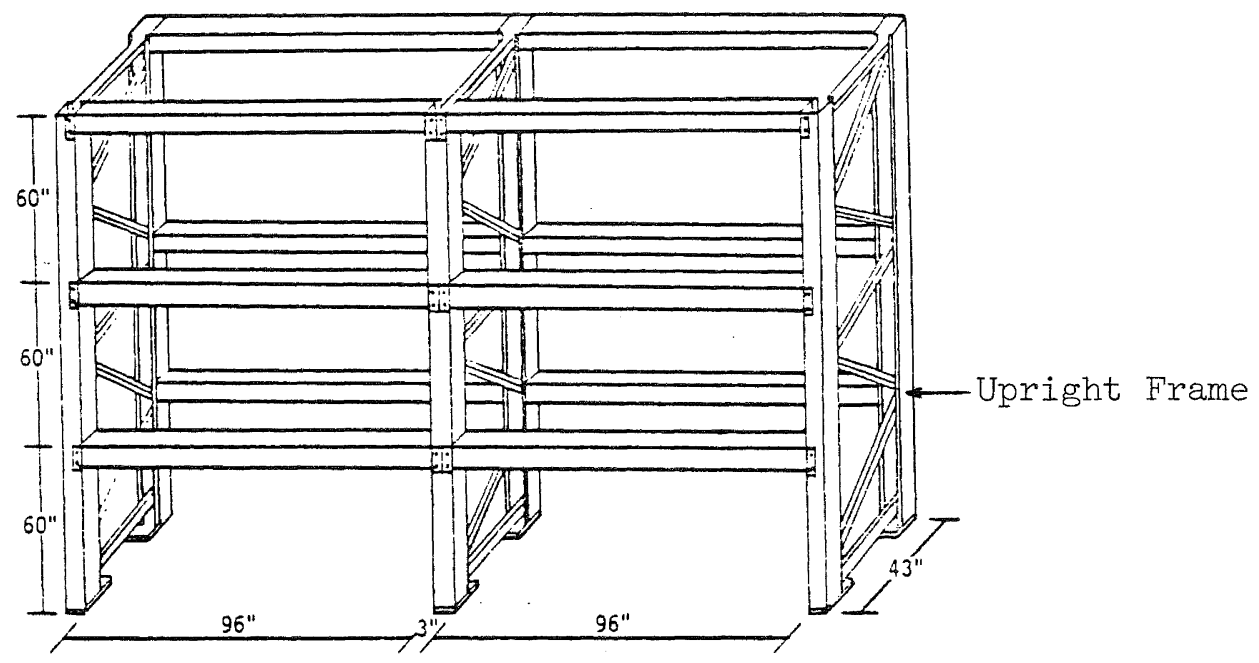

(a) STANDARD PALLET RACK

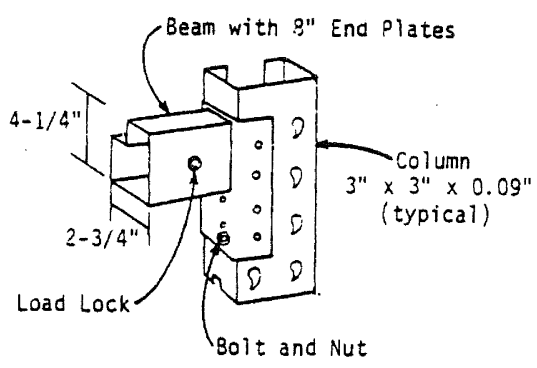

(b) SEMI-RIGID BEAM JOINT

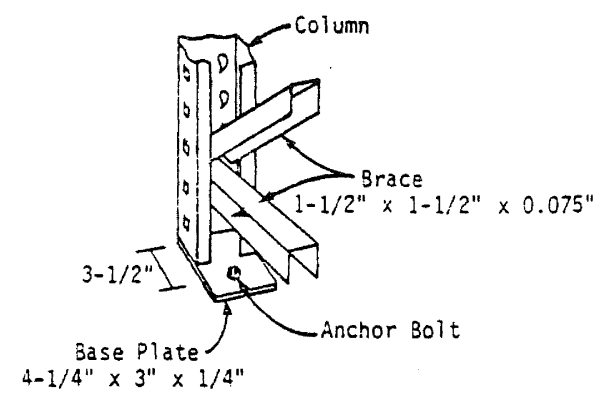

(c) DEFORMABLE BRACE TO COLUMN JOINT

FIG. 1 CONFIGURATION AND CONNECTION DETAIIS FOR STANDARD PALLET RACK (Figure 4.2 reproduced from Ref. 4)

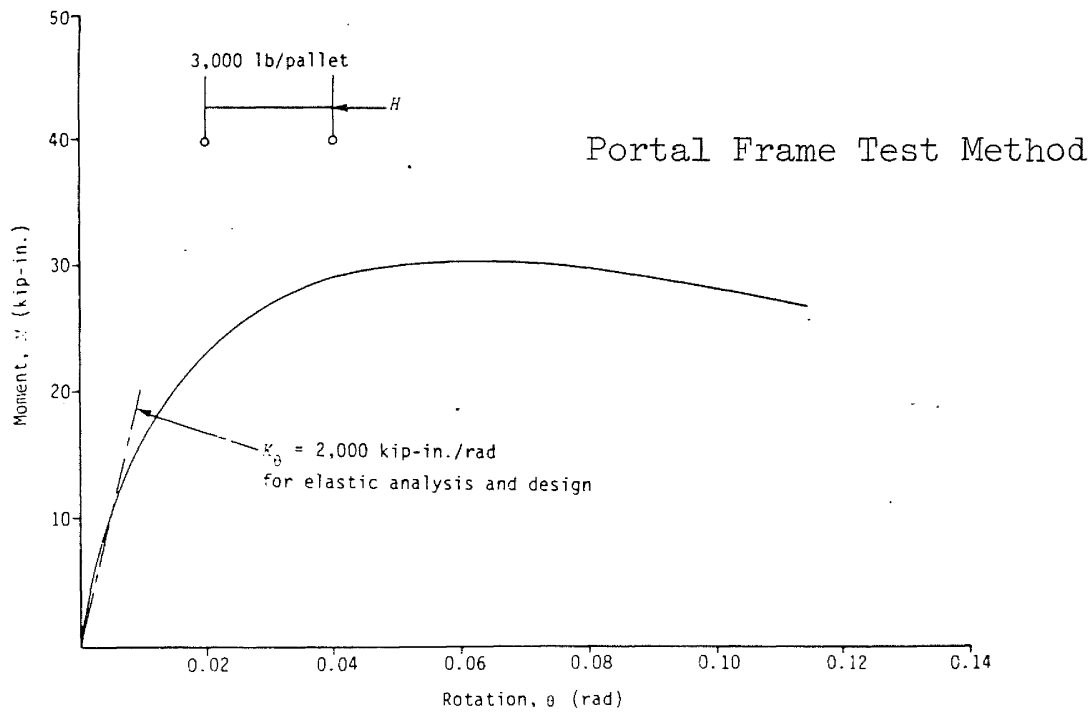

(a) Monotonic Loading

FIG. 2 MOMENT-ROTATION CURVE FOR SEMI-RIGID BEAM JOINT

(Fig. 2-29, for Rack Type B-I reproduced from Ref. 4) 
relatively low loads compared with the same failure mechanism observed in the monotonic test.

The stiffness values $K_{\theta}$ derived from sub-assembly tests provide input data for semi-rigid frame stiffness calculation, and calculation of the dynamic period.

\section{(b) Merchandise Tests}

For pallet loads of about $1000 \mathrm{~kg}$, high density load blocks were relatively stable under horizontal accelerators of up to $0.2 \mathrm{~g}$, with high accelerations being achieved with lower density blocks. Substantial diaphragm action was found to arise from friction between the pallet base, and supporting beams and rails. vertical acceleration was applied in these tests.

\section{(c) Full Scale Tests}

These were conducted on Standard and Drive In Pallet racks, in configuration two bays wide, with three seismic mass levels and height to depth ratios of the upright frames between 4 and 5 . The Drive In rack was three bays deep with longitudinal stability being provided by an anchor frame on the rear face.

These tests indicated:

(i) First mode damping values are significant (between $3 \%$ and $9 \%$ of critical in the longitudinal semi-rigid frame direction, but less $(0.5 \%$ to $3 \%$ of critical) in the transverse (upright frame direction). In both cases, higher damping is associated with higher deformation.

(ii) Fundamental periods of vibration were 2 to 3 seconds in the longitudinal direction, and 0.5 to 1.0 second in the transverse direction.

(iii) The maximum storey drift observed in the longitudinal direction was $0.07 \mathrm{H}$ for standard racks, and $0.03 \mathrm{H}$ for Drive In racks, where $\mathrm{H}$ is the storey height. The corresponding $\mathrm{P}-\delta$ contribution to storey shears was therefore a significant proportion (up to $60 \%$ ) of the total base shear, and therefore a significant factor in response prediction and member design.

Yield was observed in the critical column element (below the first mass level) at relatively low excitation levels e.g. ( $\frac{1}{4} \mathrm{El}$ Centro motion). Comparative tests indicated that $\mathrm{P}-\delta$ contribution was higher for unanchored racks (due to reduction in base fixity), with a correspondingly increased potential for frame collapse.

(iv) Inter-storey drifts in the transverse (upright frame) direction did not exceed $0.02 \mathrm{H}$. The main contribution to this drift was severe (and sometimes brittle) localised deformation occurring in the brace connections to the open lipped channel columns, which had the effect of considerably reducing the bracing stiffness.

An abstract of results for standard racks in the longitudinal and transverse directions is given in Table 1 .

$$
\frac{\text { Mathematically Modelling, and }}{\text { Response Prediction }}
$$

Theoretical response predictions, were made using a single mathematical model, and correlated with experimental observation. The model frame for Standard Pallet rack is shown in Fig. 3 and an extract of correlated properties taken from Ref. 4 is given in Table 2 .

The conclusion from these tests is that design in the longitudinal direction based on the simplified equivalent lateral force analysis, such as the ATC-3 method (Ref. 5) give base shears that are approximately equivalent to those derived using the response spectrum method, with intensity of half the El Centro record, and somewhat less than half in the transverse direction. Some adjustment is therefore required to the response modification factor recommended in ATC-3 particularly for braced upright frames.

Empirical formulae for determining the fundamental period of vibration in buildings are not suitable for rack structures and use of the Rayleigh method is recommended.

\section{APPLICATION OF NZS 4203 LOADINGS $\underline{\mathrm{CODE}}$ \\ 4.1 Introduction}

The earthquake provisions of the New Zealand Loadings Code NZS 4203 have as their basis the following performance criteria when related to Non-Public (Zone A Class III) buildings.

(i) Prevention of total collapse in severe earthquakes, such as might occur only once in the life of a structure i.e. 100 years. This leads to a strength and ductility requirement, aimed principally at limiting loss of life.

and

(ii) Control of deformation, and consequent non-structural damage, in moderate earthquakes, such as might occur three or four times in the life of the structure. This requirement is aimed at limiting the amount of economic loss, and structural damage which occurs in moderate earthquakes.

When assessing the seismic performance requirements for pallet rack structures a critical examination of these criteria is necessary. As previously noted, these structures are normally located in warehouse type buildings with below-average occupancy, and have a significantly reduced economic life 


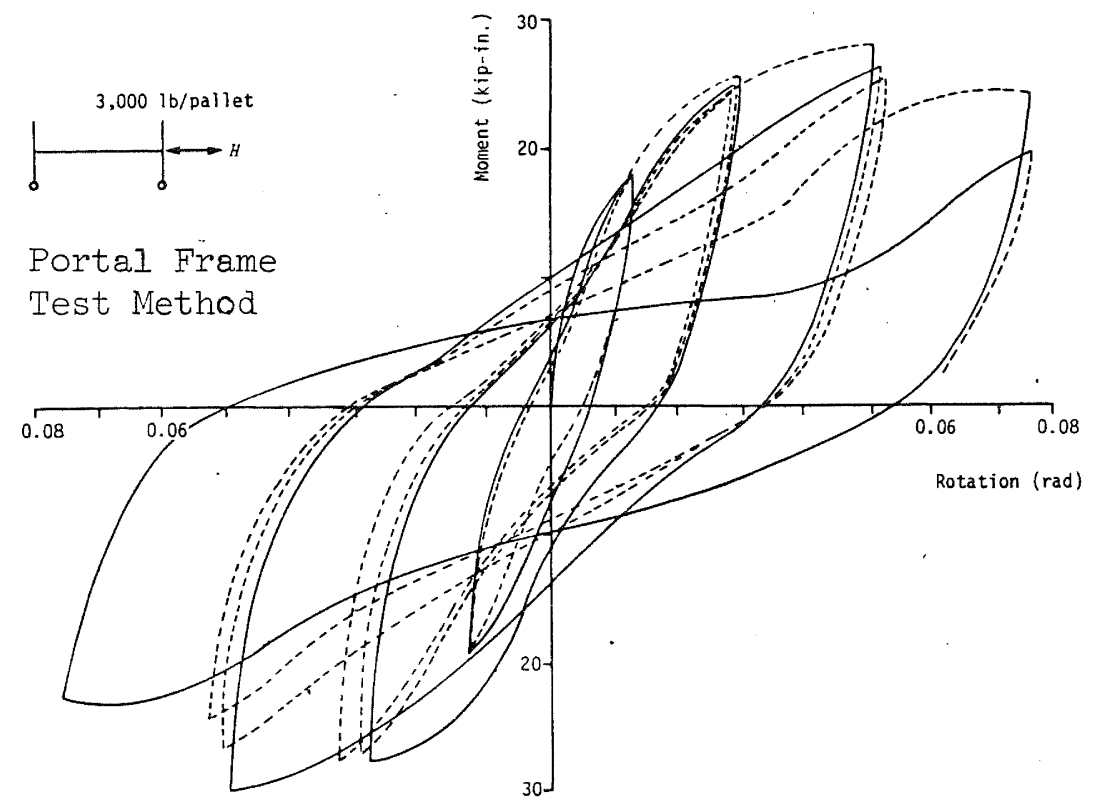

(b) Cyclic Loading

FIG. 2 MOMENT-ROTATION CURVE FOR SEMI-RIGID BEAM JOINT

(Fig. 2-30 for Rack Type B-I reproduced from Ref. 4)
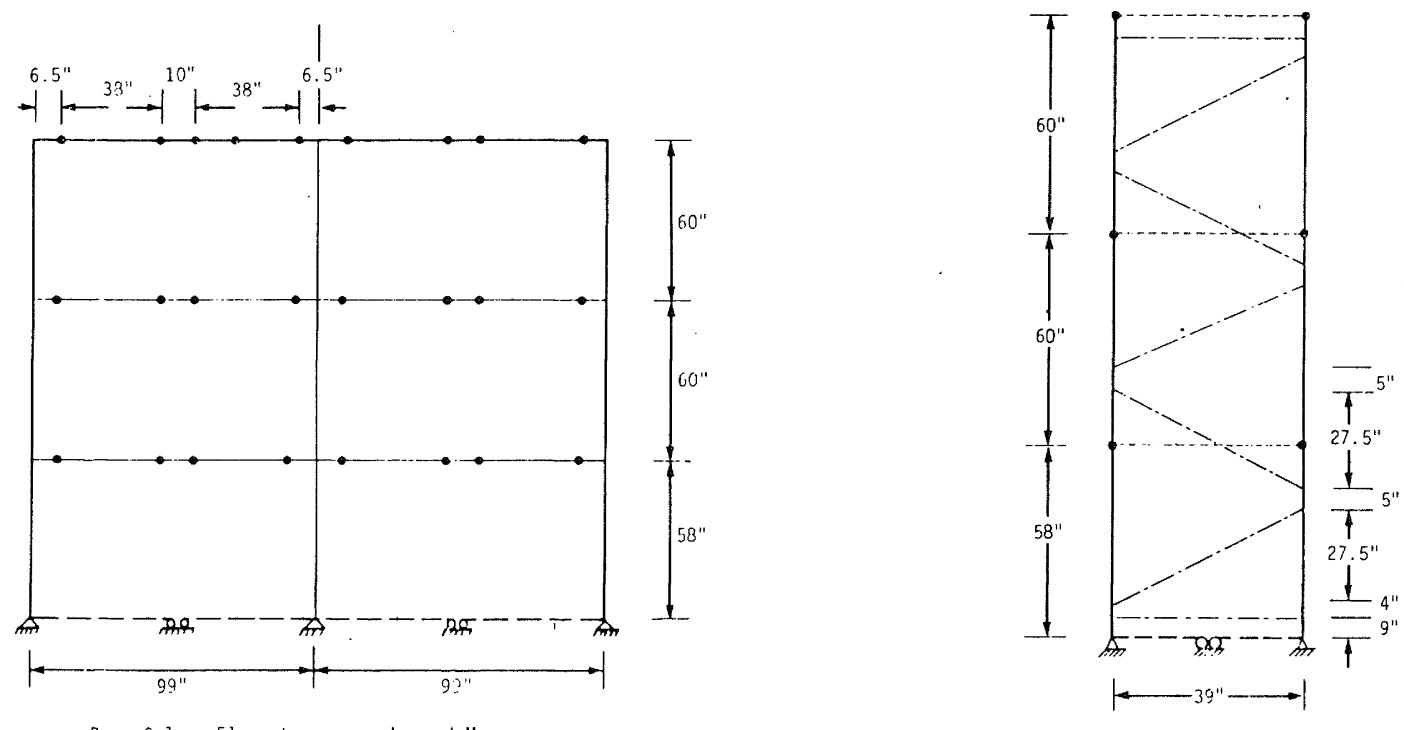

--- Fram-Column Elerient (Fictitious)

$$
\begin{aligned}
& \text { - Beam-Column Eleitent -- - Truss Element } \\
& \begin{array}{c}
\text { Beam-Column Element, } \\
\text { (Fictitious) }
\end{array} \\
& \text { - Lunizod Mass }
\end{aligned}
$$

(a) LONGITUDINAL DIRECTION (Semi-Rigid Frame)

(b) TRANSVERSE DIRECTION (Upright Frame)

FIG. 3 MATHEMATICAL MODELLING FOR STANDARD PALLET RACK

(Fig. 7.1, 8.1 reproduced from Ref. 4) 
TABLE 1 : SUMMARY OF SELECTED EXTREME QUANTITIES AND DYNAMIC PROPERTIES FOR STANDARD PALLET PACK

\begin{tabular}{|c|c|c|c|c|c|c|c|c|c|c|c|c|c|c|c|}
\hline \multirow[t]{2}{*}{$\begin{array}{l}\text { Test } \\
\text { ID }\end{array}$} & \multirow[t]{2}{*}{$\begin{array}{l}\text { Live } \\
\text { Load }\end{array}$} & \multirow[t]{2}{*}{$\begin{array}{r}\text { Table } \\
\text { Signal }\end{array}$} & \multicolumn{2}{|c|}{$\begin{array}{l}\text { Maximum Table } \\
\text { Acceleration } \\
\text { (g) }\end{array}$} & \multirow{2}{*}{$\begin{array}{l}\text { Maximum Table } \\
\text { Displacement } \\
\text { (in.) }\end{array}$} & \multirow{2}{*}{$\begin{array}{c}\text { Maximum } \\
\text { Third-Level } \\
\text { Relative } \\
\text { Displacement } \\
\text { (in.) }\end{array}$} & \multirow{2}{*}{$\begin{array}{l}\text { Maximum } \\
\text { Interstorey } \\
\text { Drift } \\
\text { (in.) }\end{array}$} & \multicolumn{2}{|c|}{$\begin{array}{l}\text { Maximum Base } \\
\text { Shear/Frame }\end{array}$} & \multirow{2}{*}{$\begin{array}{l}\text { Maximum Base } \\
\text { Overturning } \\
\text { Moment/Frame } \\
\text { (kip-in.) }\end{array}$} & \multirow{2}{*}{$\begin{array}{l}\text { Maximum } \\
\text { Ductility } \\
\text { Ratio }\end{array}$} & \multicolumn{3}{|c|}{ Period $(\mathrm{sec})^{C}$} & \multirow{2}{*}{$\frac{\text { Damping }^{\mathrm{C}}}{\left(\begin{array}{c}\text { criti- } \\
\text { call) }\end{array}\right.}$} \\
\hline & & & $\begin{array}{l}\text { Hori- } \\
\text { zontal }\end{array}$ & $\begin{array}{c}\text { Ver- } \\
\text { tical }\end{array}$ & & & & $1 \mathrm{~b}$ & ${ }_{0}^{a}$ & & & $\begin{array}{c}\text { Mode } \\
1\end{array}$ & Mode & $\begin{array}{c}\text { Mocle } \\
3\end{array}$ & \\
\hline $\begin{array}{l}120178.2 \\
(\mathrm{SP}-\mathrm{I}-2 / 3-1 / 4 \mathrm{EC})\end{array}$ & $2 / 3$ & $E C$ & 0.071 & - & 0.58 & 1.1 & $\begin{array}{c}0.57 \\
(0.001 \mathrm{H})\end{array}$ & 434 & 3.4 & 62 & 0.3 & $\begin{array}{c}1.66 \\
(1.50)\end{array}$ & 0.43 & 0.22 & $(2.9)$ \\
\hline $\begin{array}{l}120178.5 \\
(\mathrm{SP}-\mathrm{I}-2 / 3-1 / 2 \mathrm{EC})\end{array}$ & $2 / 3$ & $\mathrm{EC}$ & 0.166 & - & 1.33 & 2.7 & $\begin{array}{c}1.20 \\
(0.021 \mathrm{H})\end{array}$ & 840 & 6.6 & 100 & 0.7 & $\begin{array}{c}1.80 \\
(1.66)\end{array}$ & 0.47 & 0.22 & $(4.8)$ \\
\hline $\begin{array}{c}170178.1 \\
(\mathrm{SP}-\mathrm{I}-1-1 / 4 \mathrm{PF})\end{array}$ & Full & $\mathrm{PF}$ & 0.073 & - & 0.74 & 2.0 & $\begin{array}{c}0.93 \\
(0.016 \mathrm{H})\end{array}$ & 800 & 4.3 & 90 & 0.7 & $\begin{array}{c}2.06 \\
(2.00)\end{array} \mid$ & 0.53 & 0.26 & $(3.6)$ \\
\hline $\begin{array}{c}170178.2 \\
(\mathrm{SP}-\mathrm{I}-1-1 / 2 \mathrm{EC})\end{array}$ & Full & $E C$ & 0.162 & - & 1.33 & 4.4 & $\begin{array}{l}2.0 \\
(0.034 \mathrm{H})\end{array}$ & 1,200 & 6.4 & 145 & 1.4 & $\begin{array}{c}2.22 \\
(2.07)\end{array}$ & 0.53 & 0.26 & $(5.5)$ \\
\hline $\begin{array}{l}170178.3 \\
(\mathrm{SP}-\mathrm{I}-1-1 / 2 \mathrm{PF}\end{array}$ & Full & $\mathrm{PF}$ & 0.141 & - & 1.60 & 4.3 & $\begin{array}{c}2.3 \\
(0.040 \mathrm{H})\end{array}$ & 1,150 & 6.1 & 125 & 1.8 & $\begin{array}{r}2.30 \\
(2.25)\end{array}$ & 0.57 & 70.26 & $(5.5)$ \\
\hline $\begin{array}{c}170178.4 \\
(\mathrm{SP}-\mathrm{L}-1-5 / 8 \mathrm{EC})\end{array}$ & Full & $\mathrm{EC}$ & 0.202 & 0.110 & 1.56 & 4.9 & $\begin{array}{l}2.4 \\
(0.04 \mathrm{IH})\end{array}$ & 1,510 & 8.1 & 160 & 2.2 & $\begin{array}{c}2.75 \\
(2.35)\end{array}$ & 0.57 & 70.27 & $(9.0)$ \\
\hline $\begin{array}{c}170178.5 \\
(\mathrm{SP}-\mathrm{L}-1-7 / 8 \mathrm{EC})\end{array}$ & Full & $\mathrm{EC}$ & 0.304 & 0.163 & 2.27 & 6.8 & $\begin{array}{l}3.2 \\
(0.055 \mathrm{H})\end{array}$ & 1,640 & 8.7 & 165 & 2.4 & $\begin{array}{c}2.86 \\
(2.70)\end{array}$ & 0.57 & 70.27 & $(6.9)$ \\
\hline $\begin{array}{c}170178.6 \\
(\mathrm{SP}-\mathrm{I}-1-1 / 3 \mathrm{EC})\end{array}$ & Full & $\mathrm{EC}$ & 0.431 & 0.211 & 3.05 & 7.3 & $\begin{array}{l}4.0 \\
(0.069 \mathrm{H})\end{array}$ & 3,600 & 19.2 & 252 & 2.6 & $\begin{array}{r}2.85 \\
(2.80)\end{array}$ & 0.57 & 70.27 & $(7.6)$ \\
\hline
\end{tabular}

a. Percentage of total tributary weight ( $\Sigma \mathrm{W}=12,750 \mathrm{lb}$ for $2 / 3$ live load and 18,750 lb for full live load).

b. Ductility ratio $=\phi_{\max } / \phi_{y^{\prime}}$, where $\phi_{\max }$ is the maximum measured rotation at the top end of the center bottom column, and $\phi_{y}$ is the calculated rotation at the initiation of yield.

c. The results shown in parentheses were obtained from the shaking table decay data.

(Figures 4.12, 4.13 reproduced from Ref. 4) 
TABLE 1 : (b) STANDARD PALIET RACK - TRANSVERSE DIRECTION

\begin{tabular}{|c|c|c|c|c|c|c|c|c|c|c|c|c|c|c|c|}
\hline \multirow{2}{*}{$\begin{array}{l}\text { TEST } \\
\text { ID }\end{array}$} & \multirow{2}{*}{$\begin{array}{l}\text { Live } \\
\text { Load }\end{array}$} & \multirow{2}{*}{$\begin{array}{l}\text { Table } \\
\text { Signal }\end{array}$} & \multicolumn{2}{|c|}{$\begin{array}{l}\text { Maximum Table } \\
\text { Acceleration } \\
(\mathrm{g})\end{array}$} & \multirow{2}{*}{$\begin{array}{l}\text { Maximum Table } \\
\text { Displacement } \\
\text { (in.) }\end{array}$} & \multirow{2}{*}{$\begin{array}{c}\text { Maximum } \\
\text { Third-Level } \\
\text { Relative a } \\
\text { Displacement } \\
\text { (in.) }\end{array}$} & \multirow{2}{*}{$\begin{array}{l}\text { Maximum } \\
\text { Interstorey } \\
\text { Drift } \\
\text { (in.) }\end{array}$} & \multicolumn{2}{|c|}{$\begin{array}{l}\text { Maximum Base } \\
\text { Shear/Frame }\end{array}$} & \multirow{2}{*}{$\begin{array}{l}\text { Maximum Base } \\
\text { Overtuming } \\
\text { Moment/Frame } \\
\text { (kip-in.) }\end{array}$} & \multirow{2}{*}{$\begin{array}{r}\text { Maximum } \\
\text { Ductility } \\
\text { Ratioc }\end{array}$} & \multicolumn{3}{|c|}{ Period (sec) } & \multirow{2}{*}{$\begin{array}{l}\text { Damping } \\
\text { (o cri- } \\
\text { tical) }\end{array}$} \\
\hline & & & $\begin{array}{l}\text { Hori- } \\
\text { zontal }\end{array}$ & $\begin{array}{l}\text { Ver- } \\
\text { tical }\end{array}$ & & & & $\mathrm{lb}$ & $\frac{a b}{b} b$ & & & $\begin{array}{c}\text { Mode } \\
1\end{array}$ & $\begin{array}{c}\text { Mode } \\
2\end{array}$ & $\begin{array}{c}\text { Mode } \\
3\end{array}$ & \\
\hline $\begin{array}{c}240178.1 \\
(\mathrm{SP}-\mathrm{T}-2 / 3-1 / 4 \mathrm{EC})\end{array}$ & $2 / 3$ & EC & 0.073 & - & 0.61 & $\begin{array}{l}0.9(\mathrm{~W}) \\
1.0(\mathrm{C}) \\
0.9(\mathrm{E})\end{array}$ & $\begin{array}{c}0.40 \\
(0.007 \mathrm{H})\end{array}$ & 1,120 & 13.1 & 150 & 0.3 & $\left|\begin{array}{l}0.71 \\
0.68)\end{array}\right|$ & p.24 & - & $(1.0)$ \\
\hline $\begin{array}{c}260178.1 \\
(\mathrm{SP}-\mathrm{T}-1-1 / 4 \mathrm{EC})\end{array}$ & Full & $\mathrm{EC}$ & 0.077 & - & 0.62 & $\begin{array}{l}1.3(\mathrm{~W}) \\
1.4(\mathrm{C}) \\
1.3(\mathrm{E}) \\
\end{array}$ & $\begin{array}{c}0.59 \\
(0.010 \mathrm{H}) \\
\end{array}$ & 1,650 & 3.2 & 200 & 0.8 & $\left|\begin{array}{c}0.87 \\
(0.85)\end{array}\right|$ & 0.28 & - & (1. $)$ \\
\hline $\begin{array}{c}260178 / 2 \\
(\mathrm{SP}-\mathrm{T}-1-1 / 4 \mathrm{PF})\end{array}$ & Full & $\mathrm{PF}$ & 0.077 & - & 0.80 & $\begin{array}{l}1.0(\mathrm{~W}) \\
1.1(\mathrm{C}) \\
1.0(\mathrm{E})\end{array}$ & $\begin{array}{c}0.46 \\
(0.008 \mathrm{H})\end{array}$ & 1,200 & 9.6 & 160 & 0.6 & $\left|\begin{array}{c}0.89 \\
(0.85)\end{array}\right|$ & 0.30 & - & $(1.2)$ \\
\hline $\begin{array}{c}260178.3 \\
(\mathrm{SP}-\mathrm{T}-1-1 / 2 \mathrm{EC})\end{array}$ & Full & $\mathrm{EC}$ & 0.158 & - & 1.29 & $\begin{array}{l}2.8(\mathrm{~W}) \\
2.3(\mathrm{C}) \\
1.8(\mathrm{E})\end{array}$ & $\begin{array}{l}1.05 \\
(0.018 \mathrm{H})\end{array}$ & 2,550 & 20.4 & 280. & 1.9 & $\left|\begin{array}{c}0.92 \\
(0.90)\end{array}\right|$ & 0.30 & - & $(1.0)$ \\
\hline $\begin{array}{c}260178.4 \\
(\mathrm{SP}-\mathrm{T}-1-5 / 8 \mathrm{EC})\end{array}$ & Full & $E C$ & 0.200 & 0.120 & 1.57 & $\begin{array}{l}2.5(\mathrm{~W}) \\
2.5(\mathrm{C}) \\
2.0(\mathrm{E}) \\
\end{array}$ & $\begin{array}{l}1.10 \\
(0.019 \mathrm{H})\end{array}$ & 2,780 & 22.2 & 310 & 2.1 & $\left|\begin{array}{c}0.95 \\
(0.92)\end{array}\right|$ & 0.30 & - & $(1.6)$ \\
\hline
\end{tabular}

a. $\mathrm{W}=$ west frame, $\mathrm{C}=$ centre frame, $\mathrm{E}=$ east frame.

b. Percentage of total tributary weight ( $\Sigma \mathrm{W}=8,500 \mathrm{lb}$ for $2 / 3$ live load and 12,500 lb for full live load̃).

c. Ductility ratio $=\phi_{\max } / \phi_{\mathrm{y}}$, where $\phi_{\max }$ is the maximum measured rotation near the base of the centre bottom column, and $\phi_{\mathrm{y}}$ is the calculated $\mathrm{y}^{\prime}$ rotation max $_{\text {the }}$ initiation of yield.

d. The results shown in parentheses were obtained from the shaking table decay data. 
requirement when compared with the buildings which enclose them. While collapse of the structure is to be avoided, particularly if severe damage to the building results as a consequence significant merchandise loss from spillage is acceptable in major earthquakes. In moderate earthquakes, some damage to the elements of the rack structure is acceptable (due to the ease of component replacement), but economic loss through spillage of palletised goods needs to be minimised. Deformation limits themselves (as might apply to buildings) are not relevant except insofar as they affect strength requirements by contributing to progressive collapse i.e. P- $\delta$ effect or permit paliets to drop between elements of the support structure.

Tentative seismic performance criteria for rack structures might therefore be stated as:

(i) Prevention of total collapse in a severe earthquake, through provision of adequate reserve strength and/or ductility but accepting significant spillage to palletised goods in these circumstances.

and

(ii) Minimisation of economic loss through spillage of palletised goods, while accepting large deformations, and limited damage to the pallet rack structure in moderate earthquakes.

Intuitively, these requirements are best achieved by seeking to limit the amplification of ground motions by the structure, by providing high damping and/or ductility or by deliberately selecting a long period system, or by providing some means of base isolation.

\subsection{Economic Life and Importance Factor}

The NZS 4203 Earthquake Design Spectrum originated from the 1965 Loadings Code, and its derivation is discussed in detail in the commentary to the latter code (Ref. 6). While there is currently no direct provision for designers to specifically select an economic life, or relate that life to a return period between earthquakes of specified intensities, the Importance factor (NZS 4203 Table 4) does partially relate to these aspects.

Using the approach outlined in Ref. 7, it can be shown that a Class III Building in zone $A$ ( $I=1.0$ and design life of 100 years) has one chance in two of being exposed to an earthquake intensity whose return period is 150 years or greater). If the design life of a rack structure were taken as half that for a Class III building i.e. reduced to 50 years, then given the same probability of exceedence during the design life, the corresponding earthquake intensity would be lower, i.e. associated with a design earthquake return period of 73 years, or approximately half the original return period. Using an approximate correlation between peak ground acceleration, and Modified Mercalli Intensity, it can be shown that the peak ground acceleration for the rack structure could be reduced to about $70 \%$ of that for the enclosing building.

On this basis, a reduction of Importance factor I from 1.0 to 0.7 for demountable rack structures seems justified.

\subsection{Structural Type "S" Factors}

NZS 4203, in Clause 3.3 .7 , permits the use of special studies for structural systems not covered by normal code providions, so that appropriate $S$ factors can be selected.

The Structural Type Factor "S"

(NZS 4203 Table 5) relates to the potential seismic performance of different types of structural system and reflects both the inelastic capacity (in yielding type structures) and equivalent viscous damping (in elastically responding non-yielding structures). For the latter type, a correlation between different levels of equivalent viscous damping, and the "S" factor has been adapted from Ref. 8 and shown graphically in Fig. 4. This is based on spectrum amplification factors derived by Newmark and Hall for a viscously damped single degree of freedom oscillator and pegged by the NZS 4203 criteria that $S=6$ for $2 \%$ damping.

Assuming from results summarised in section 3 that energy dissipation is available in pallet rack structures through elastic damped response then $S$ factors can be allocated as shown in Table 3. The deformation limits, and corresponding damping percentages are taken from Table 1 with input corresponding to about half the El Centro or Parkfield ground motion.

The $S$ factors proposed in Table 3 reflects adequately the damped elastic response in the longitudinal frame direction. However, in the transverse direction, the $S$ factor obtained using $2 \%$ damping appears to predict excessively high levels of base shear. It is suggested that this arises because the damping correlation used is obtained from motion decay data, and does not adequately reflect the limited ductility available from inelastic deformation in the brace to column joint.

Using the equal energy criterion to scale the elastic response of short period structures

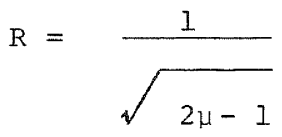

where $\mathrm{R}$ is the amplification modification factor and $\mu$ is the displacement ductility demand in the equivalent elasto-plastic structure, the reduction $S$ from 6.0 to 3.0 is found to correspond with imposing a ductility demand of $\mu=2.5$ on the upright frame with a specified yield point set at $\mathrm{S}=3.0$. Nomination of a specified ductility demand would require experimental verification, and is discussed further in Section 5 . 
TABLE 2: SUMMARY OF FORMULAE FOR MATHEMATICAL MODELLLING (From Ref. 4)

\section{LONGITUDINAL (SEMI-RIGID) FRAME DIRECTION}

(a) Semi-Rigid Joint Stiffness $-\mathrm{K}_{2}=1000$ to $1500 \mathrm{kp}-\mathrm{in} / \mathrm{radian}$ : $=56$ to $112 \mathrm{kN}-\mathrm{m} / \mathrm{radian}$ Selection $\mathrm{K}_{\theta}$, and damping percentage dependant on amplitude of ground motion.

(b) For Conventional Rigid Frame Analysis, Model Semi-Rigid Joint by Adjusting Original Beam Stiffness Using Relationship

$$
\left(\frac{I_{b}}{I_{b}}\right)_{\text {reduced }}=\left[\frac{\frac{1}{6 E I_{b}}}{1+\frac{b}{K_{\theta} I_{b}}}\right]\left(\frac{I_{0}}{I_{b}}\right)_{\text {gross }}
$$

Where $L_{b}$ is moment of inertia of beam length $L_{b} ; K \theta$ is semi-rigid joint stiffress;
$\mathrm{E}$ is

2. MOMENT OF INERTIA OF FICTITIOUS FLOOR BEAM, RESTRAINED SEMI-RIGID COLUMN BASE

Fictitious floor beam (Longitudinal and transverse frames). Moment of inertia: $I_{f}=0.2 \mathrm{in}^{4}\left(0.083 \times 10^{6} \mathrm{~mm}^{4}\right)$

\section{TRANSVERSE (UPRIGHT FRAME) DIRECTION}

Bracing Stiffness Reduction Factor $k$, to account for local deformation in brace to column connection is defined by:

$$
\left(\frac{E A}{l}\right)_{\text {reduced }}=\frac{1}{\bar{k}}\left(\frac{E A}{l}\right) \text { gross }
$$

Where $k$ ranges 7-12 from test; $l$ is the brace length; $E_{S}$ is Youngs Modulus (Steel); A is cross section area of brace.

TABLE 3 : N.Z.S. 4203 STRUCTURAL TYPE FACTORS FOR PALLET RACK STRUCTURES ASSUMING ELASTIC DAMPED RESPONSE

\section{Standard Pallet Rack and Drive-In Rack}

Values of Parameters

Assumed

1. Damping Range

2. Deformation Range

3. "S" Factor (Fig. 4)

4. Experimental Base Shear

(as proportion of Gravity Load)

5. Fundamental Period (Sec)

6. $C_{d}$ from NZS 4203 (Zone A, $I=0.7$ )
Longitudinal

(Semi-rigid Frame)
Transverse

(Upright Lattice Frame)

\section{Damped Elastic Response}

$$
\begin{array}{ll}
\text { SP } & 0.04 \mathrm{H} \\
D I & 0.03 \mathrm{H} \\
& 2.5 \\
& \\
& 0.08 \\
2.3-2.5 & \\
& 0.11
\end{array}
$$$$
0.08
$$

Limited Ductile Response

$$
0.02
$$

$0.015 \mathrm{H}$

$0.015 \mathrm{H}$

6.0

3.0

0.20

$0.6-0.8$

0.25

NOTES :

i Data lines $1,2,4$ and 5 are extracted directly from Table 1 .

Note that damping percentages listed are derived from shaking table motion decay data. 
Selection of the appropriate $S$ value for transverse upright frames should be coupled with a check against the minimum base shear required to induce rocking response (discussed in section 4.4) or to yield the base anchorage.

\subsection{Response in Severe Earthquakes}

Capacity design concepts are inherent in the NZS 4203 approach to seismic resistant design, particularly in those elements or structural systems depending on medium or high ductility demand to survive severe earthquakes. While the R.M.I. tests demonstrate that significant energy absorption capability is available (through elastic damped response in the ease of semi-rigid frame joints in the long frame direction, or limited ductility demand through deformation in the brace to column joints, and at the column bases), they do not verify the ability of critical sections of the rack structure to undergo larger deformations into the plastic range. Consequently, it is improbable that existing cold formed designs can be utilised and comply with capacity design requirements without some change in the structural concept. Suitable concepts that take account of the capacity design requirements of NZS 4203 (and which also satisfy the second seismic performance criterion for rack structures discussed in Section 4.1) have been developed for other structural types, and could reasonably be incorporated in existing rack design. Some examples are:

(i) Base Isolation Through Rocking Response

Earthquake motions in the transverse direction will induce uplift in the columns of upright lattice frames, depending on the height to depth ratios of the frames. It can be shown that, for an inverted triangular seismic load distribution on a frame of height $\mathrm{H}$ and depth $\mathrm{D}$ between the columns, uplift will occur when ground acceleration $E$ exceeds the value;

$$
E=\frac{0.75}{(\mathrm{H} / \mathrm{D})}
$$

e.g. for $H / D=5$, uplift will occur at $0.15 \mathrm{~g}$.

This uplift has the effect of lengthening the natural period of the frame, and providing additional energy dissipation (or damping) by raising and lowering the stored mass. The equivalent viscous damping of this system is therefore amplitude dependent, and capable of adjusting to the input ground motion.

A design method, based on Housner's Rocking block as reported by Priestley and others (Ref. 9, 10), can be adapted to predict response accelerations and displacements in the upright frames for any specified ground motion.
The structural design of the upright frame needs to take account of this mode of response, to ensure that adequate strength margins exist in all members to permit rocking to occur. Base plates need to be suitably detailed, and adequate separations provided to adjacent building components, to permit the anticipated displacements to occur. The distribution of specifically designed rocking upright frames within the total rack structure depends on the type of rack, the likely load distribution at the time of the earthquake, the height to depth ratio of the upright frames, and costs.

\section{Supplementary Bracing Systems}

The tendency for stiffness degradation in the semi-rigid beam to column joints has been referred to in section 3 . It is normal practice to detail seismic connections of any type with a strength margin in the joint fastener design to force yielding to occur in other sections of the member where the mode of deformation is more ductile and reliable. Hence, the type of semi-rigid joint typically used in rack structures, as reported in the R.M.I. tests are not considered suitable as primary seismic resisting elements, and have specifically been precluded in NZS 3404 Clause 3.2 . However, their contribution to structural damping, and frame stiffness (at low to medium deformation) need to be taken account of in design.

Longitudinal frame collapse will occur when, during the ground motion, the $\mathrm{P}-\delta$ increments exceed the total restoring force available from the semi-rigid joints. For a specified deformation limit, and equivalent viscous damping, a supplementary bracing system of similar stiffness, but greater tenacity can be used to assist the semi-rigid frame action.

Mild steel bracing is satisfactory for strength, but can be excessively stiff if oversized, and promote spillage in moderate earthquakes. Steel wire rope, while lacking the energy dissipation capability available through plastic deformation does meet the strength and stiffness requirements. The use of energy dissipation in major installations is also worth consideration.

A design example, for a drivein storage rack application, which incorporates the above concepts is included as Appendix $A$ at the end of this paper. 


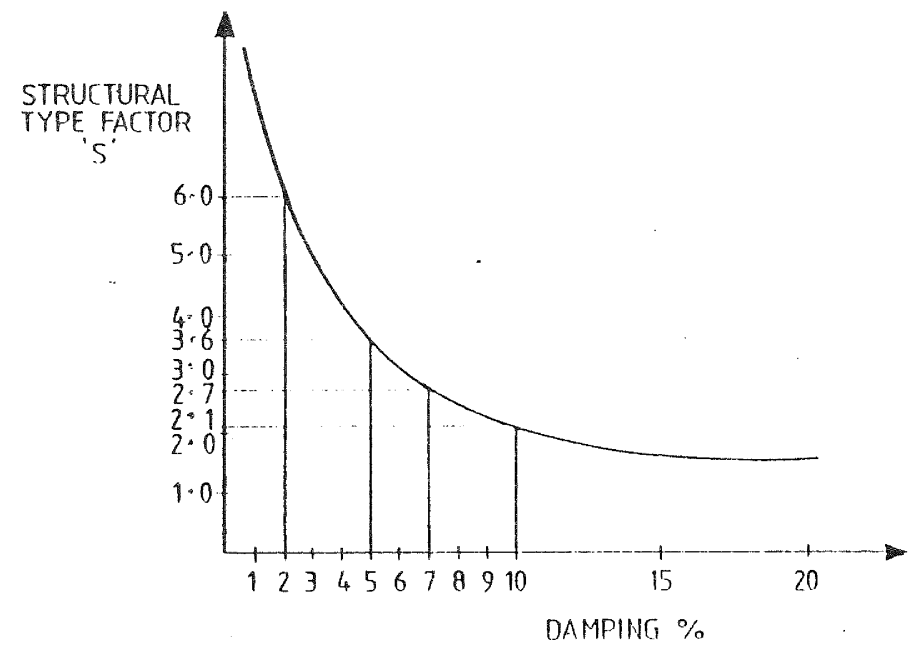

FIG. 4 NZS 4203 STRUCTURAL TYPE ("S") FACTORS FOR ELASTICALLY RESPONDING STRUCTURES WITH VARYING PERCENTAGES OF CRITICAL DAMPING (Adapted from Ref. 8)

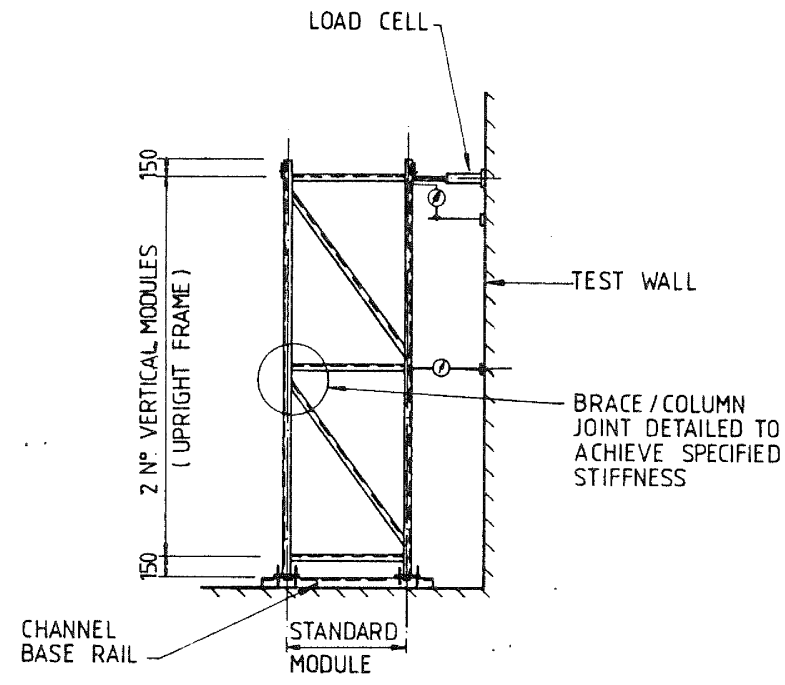

FIG. 5 PROPOSED ASSEMBLY FOR CYCLIC LATERAL LOAD TESTS ON UPRIGHT FRAME MODULES

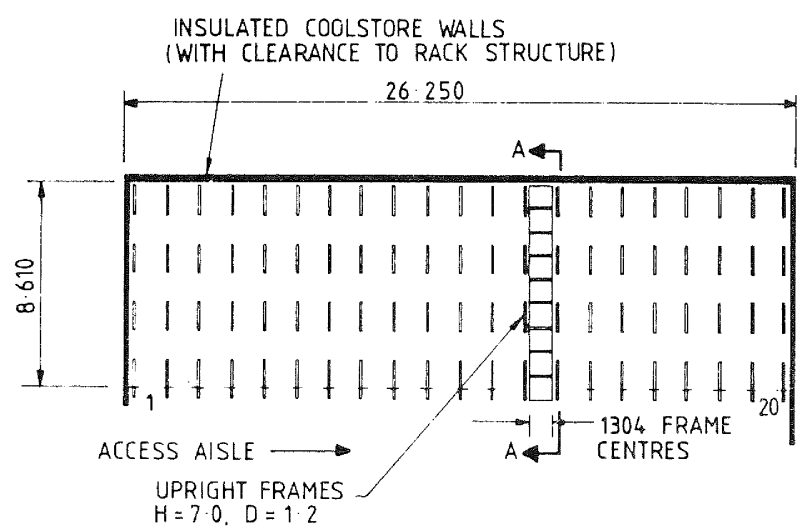

DRIVE IN RACK LAYOUT IN COOLSTORE

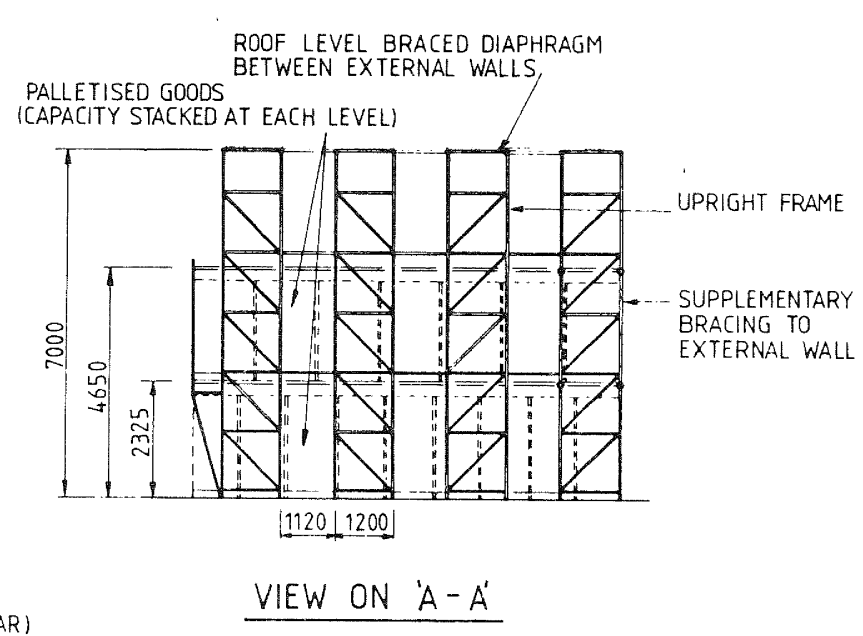




\section{DESIGN METHODS \\ 5.1 Experimentally Based Designs}

Traditional design methods for pallet racks, principally for gravity loads have been developed from full scale, and subassembly testing similar to that described earlier. For seismic loading NZS 4203 (commentary Clause C3.2.2) sets out criteria for achieving "adequate ductility" in building frames, by specifying the maximum strength loss permissible in a frame after eight cycles to deformation corresponding to a displacement ductility of four.

The current New Zealand Steel Code (Ref. 11) in Clause 3.2 .5 permits experimentally based design, with the appropriate NZS 4203 load factors increased by $20 \%$. For cold formed structures, the Australian Code (Ref. 12) further permits localised distortions (such as at brace to column joints in upright frames) to commence at $65 \%$ of the global load factor.

For an upright frame designed for limited ductility (with displacement ductility factor of say 2.5 rather than four) experimental verification of cyclic load resistance of a modular design to meet requirements of NZS 4203 can be obtained using a test assembly such as shown in Fig. 5. Similar verification for a capacity load condition i.e. rocking response, would require a minimum load factor of 1.3 with design gravity load being taken on one column of the frame after a specified number of cycles.

\subsection{Materials Codes}

While there is currently no endorsed New Zealand Standard for cold formed steel design, preference is for the adoption of either AS 1538 (Ref. 12), or the American A.I.S.I. (1980) Specification (Ref. 13). The American National Standard applicable to Pallet Racking i.e. (M.H. 16.1 - 1974/Ref 14) is based on the 1968 edition of the A.I.S.I. Specification, and would appear to be the most suitable base document for a New Zealand Pallet Rack Design Recommendation. For proportioning cold formed members subject to seismic loading, ATC-3 recommends a strength method approach, with a scale factor of 1.67 on working stress levels, and a strength reduction factor $\phi=0.9$ for normal applications. A lower $\phi$ value would apply in low temperature applications, where brittle fracture is likely. Moment redistribution (as NZS 3404 Clause 14.1.2) would not apply unless section strength is governed by plasticity rather than stability criteria.

\subsection{Gravity Load Distribution Concurrent}

The uniform distribution of seismic resisting elements e.g. upright frames, in the rack structure means that, while an individual frame may be fully loaded in an earthquake, the average occupancy level within the rack would be significantly less. This arises both from the number of vacant spaces in the rack and the pallet overload margin normally specified at the time of purchase. Hence more widely separated elements e.g. supplementary longitudinal bracing anchored to the floorslab between back to back standard pallet racks, would be proportioned for the average, rather than capacity storage load. An (albeit reduced) proportion of these gravity loads is also likely to contribute to preventing uplift of the base anchorage and floor-slab.

For a storage occupancy level of two-thirds, with the rack self weight being approximately 5\% of the stored mass, the average seismic base shear can be based on $\mathrm{W}_{+}=0.70$ to 0.75 times the capacity storage load.

For drive-in racks, with supplementary bracing along exterior walls providing stability in the longitudinal direction, the likelihood of slab uplift occurring when pallet frames adjacent to exterior walls are unloaded, while spaces more central in the store are occupied and contributing fully to seismic shear, must be considered. This design problem can to some extent be overcome by requiring suitable procedures in rack management and operation.

\section{BUILDING DESIGN ASPECTS}

Pallet rack structures normally rely totally on anchorage or reaction at floor level for stability under earthquake loading. The adequacy of the floor system to resist these loads often dictates the type of lateral force resisting system that can be used, often at the expense of rack performance.

The following are recommended features for buildings containing pallet rack structures designed to these requirements :

7.

Provision of reinforced groundslabs, or wearing slabs, with adequate strength to resist uplift loads from a centrally located bracing anchorage in severe earthquakes.

Inclusion of strong bands within the floorslab, or wall skirtings at exterior walls to anchor longitudinal supplementary bracing where drive-in type racks are proposed.

Provision of adequate clearances between external walls and rack frames to permit the expected rack deformations to occur without damage to the building fabric.

COSTS AND BENEFITS:

For the product coolstore installation shown in Fig. 6 , the following comparative costs would apply (1981 prices):

Cost of stored Goods (e.g.

kiwifruit) $=\$ 1,500 /$ pallet space

Building Cost Inc. Services

(a $\left.\$ 600 / \mathrm{m}^{2}\right)=\$ 300 / \mathrm{pallet}$ space 
Pallet Racking (installed cost) $=\$ 75 /$ pallet space.

At about $4 \%$ of the sunk cost the investment in racking structures is small, compared with the write off cost should collapse or large scale spillage occur under earthquake attack.

The additional investment required to provide improved protection against economic loss through spillage of high value, perishable palletised goods particularly in moderate earthquake appears to be commercially justifiable from the national viewpoint.

\section{CONCLUSION:}

While cold formed steel is not highly regarded as a material suitable for seismic resistant design, full scale tests carried out in the United States on pallet rack structures indicate that relatively high damping levels can be achieved through deformation in semirigid frame joints, and that the performance of traditional rack designs in terms of limiting spillage of palletised goods is satisfactory in moderate earthquakes.

It is suggested that by selecting seismic design criteria appropriate for moderate earthquakes, satisfactory systems meeting the requirements of NZS 4203 Loadings Code can be developed using cold formed steel. This requires the adoption of suitable base isolation mechanisms, such as rocking response, and utilising the high damping, deformability and limited ductility available in existing module designs.

In acknowledgement of the temporary nature of these structures, the design earthquake level is proposed at $70 \%$ of that for a Class III (non-public building), provided that adequate provision is made in the design of both the rack, and its enclosing building, for response to severe earthquakes.

\section{ACKNOWLEDGEMENTS}

The material in this paper has been prepared by the author on behalf of the Heavy Engineering Research Association Inc., as background for a proposed H.E.R.A. Design Guide for Pallet Racking Systems. Opinions expressed are those of the author, and are not necessarily those of H.E.R.A. The permission of U.R.S./John A. Blume and Associates, and R.M.I. to publish extracts from their 1980 report is acknowledged.

10. BIBLIOGRAPHY

(1) "Specification for Design, Testing and Utilisation of Industrial Steel Storage Racks". Rack Manufacturers Institute, Pittsburg, USA (May 1980). Adopted with minor amendments as Ref. 14 .

(2) "Code of Practise for Design of static Racking". Storage Equipment Manufacturers Association (SEMA), London. (1980).
NZS 4203: "Code of Practise for General Structural Design and Design Loadings for Buildings". SANz (1976, including Amendments No. 1, 2).

"Seismic Study of Industrial Steel Storage Racks." C.K. Chen, R.E. Scholl, and J.A. Blume (URS/John A Blume and Associates, Engineers, San Francisco for National Science Foundation/ Rack Manufacturers Institute) $477 p$. June 1980 .

Applied Technology Council: "Tentative Provisions for Development of Seismic Regulations for Buildings" (Publication ATC 3-06). California. June 1978.

"Commentary on Chapter 8 of NZS 1900" NZ Standards Institute (now SANZ). Miscellaneous Publication MP 12:1965. Dec. 1965 .

"Seismic Risk and Design Criteria". A.V. Hatrick. Bull, NZ Society

for Earthquake Engineering Vol. 13 No. 1 March 1980. (pp 14-21).

"Elastic Response "S" Factors". Private Communication, R.C. Cooney (17.11.81). Reference "Fundamentals of Earthquake Engineering", N.M. Newmark, E. Rosenblueth (Prentice Hall 1971 ) Table 9.1.

"Seismic Response of Structures Free to Rock on their Foundations" M.J.N. Priestley, R.J. Evison, A.J. Carr. Bull. N.Z. Society for Earthquake Engineering Vol. Il No. 3 Sept. 1978 (pp 14l-150).

"Recommendations for the Design and Construction of Base Isolated Structures". R.W.G. Blakeley, A.W. Charleson, H.C. Hitchcock, L.M. Megget, M.J.N. Priestley, R.D. Sharpe, R.I. Skinner. Bull. N.z. Society for Earthquake Engineering Vol. 12 No. 2 June 1979, pp. 136-157.

NZS 3404:1981, "Steel Structures Code" (incorporating AS 1250:1981). SANZ, Wellington.

AS 1538:1974 "SAA Cold Formed Steel Structurers Code" ASA, (based on 1968 Edition Ref. 13).

"Specification for the Design of Cold Formed Steel Structural Members". American Iron and Steel Institute (AISI) Sept. 1980.

ANSI : MH 16.1 - 1974 "American National Standard Specification for Design Testing, and Utilisation of Industrial Steel Storage Racks" (New York, 1974). 


\section{APPENDIX A: DESIGN EXAMPLE FOR DRIVE-IN STORAGE RACK}

The following outline calculations for the Drive-In Storage Rack shown in Fig. 6, illustrates the concepts discussed in the text.

ASSUME

(i) Location Zone 'A' on soft ground.

(ii) Standard gravity frame in cold formed steel including semi-rigid anchor frame to rear wall.

(iii) Seismic resistance to be provided by: Roof level: Braced diaphragm between external bracing.

Lateral

Direction: Rocking response on all frames.

Longitudinal

Direction: Supplementary bracing, with base anchorage to wall skirtings.

Assessment of Seismic Response:

(a) Elevated Loading - storage capacity 9 No. $1000 \mathrm{~kg}$ pallets at 2No. levels on $8.610 \mathrm{~m}$ deep bay i.e. $9000 \mathrm{~kg} /$ level/bay, and 20No. bays to each side.

(b) Seismic Loads in Transverse Direction -

(i) Capacity Mass Density = $\frac{2 \times 9000 \mathrm{~kg}}{4 \text { No. Frames }}=4,500 \mathrm{~kg} /$ frame

Assume mass uniformity distributed over total frame area $\left(8.4 \mathrm{~m}^{2}\right)=535 \mathrm{~kg} / \mathrm{m}^{2}$.

(ii) Minimum base acceleration for Rocking Response

$$
\begin{aligned}
& E=\frac{0.75}{(\mathrm{H} / \mathrm{D})}=\begin{array}{l}
0.128 \text { compare } \\
\mathrm{S}=6 \text { response } \\
(\mathrm{T}<0.6 \mathrm{sec})
\end{array} \\
& C_{\mathrm{d}}=\text { CISMR }=\begin{array}{r}
0.15 \times 0.7 \times 6.0 \\
\times 0.8 \times 1.0=.504
\end{array} \\
& \therefore \text { Design for rocking response. }
\end{aligned}
$$

(iii) Rocking Analysis (from Ref. 9)

Assume $70 \%$ of capacity storage as seismic live load i.e.

$375 \mathrm{~kg} / \mathrm{m}^{2}$. Total Mass $\mathrm{M}=$

$3150 \mathrm{~kg}$, Weight $\mathrm{W}=30.9 \mathrm{kN}$.

Rotational Inertia $I_{0}=$ $\mathrm{m}\left(\frac{\mathrm{DH}^{3}}{12}+\frac{\mathrm{D}^{3} \mathrm{H}}{12}\right)+\mathrm{MR}^{2}=52939 \mathrm{~kg}-\mathrm{m}^{2}$

Period $T=\frac{4}{\rho} \cosh ^{-1}\left[\frac{1}{1-\frac{\Delta R}{D}}\right]$

for displacement

$\Delta_{\mathrm{R}}$ at top of frame,

and where

$\rho=\sqrt{\frac{W R}{I_{0}}}=1.44$
Kinetic Energy reduction factor

$r=\left(1-\frac{M R}{I_{0}}\left(1-\cos \left(\frac{2 D}{H}\right)\right)^{2}=0.912\right.$

Equivalent viscous damping $\lambda=\frac{\rho r T}{8 \pi}=0.0522 \mathrm{~T}$

Graphical solution, using smoothed tri-

partite response spectrum gives:

$$
\begin{array}{ll}
\text { Period of Rocking } & =1.2 \mathrm{sec} \\
\text { Equivalent Viscous } & =6 \% \\
\text { Damping } & =95 \mathrm{~mm} \\
\text { Spectral displacement } & =9
\end{array}
$$

Design upright frames to

support $4500 \mathrm{~kg}$ on single leg, with 1.3

load factor for impace. Allow margin,

say $50 \%$ on spectral displacement for

clearance to building fabric i.e. $150 \mathrm{~mm}$.

(c)

\section{Seismic Response in Longitudinal Direction}

(i) Local Response to face loaded upright frame (assume $I_{x x}=5 \times 10^{6} \mathrm{~mm}^{4}$ ) and capacity storage.

Period $\mathrm{T}=\frac{2 \mathrm{~L}^{2}}{\tau \tau} \sqrt{\frac{\mathrm{W}}{\mathrm{EI}}}=0.79 \mathrm{sec}$

Where $L=7 \mathrm{~m}, W=4500 \mathrm{~kg}$ on $7 \mathrm{~m}=643 \mathrm{~kg} / \mathrm{m}$, $\mathrm{E}=200^{\circ} \times 10^{9} \mathrm{~N} / \mathrm{m}^{2}$

Amplified response (assume 5\% damping from friction on pallet rails, and movement in local blocks, and $\mathrm{A}_{r}=3$ for elastic response).

$C_{p}=0.13 \times 0.7 \times 3.0=0.273$ in design earthquake.

$W_{p}=0.273 \times 643 \mathrm{~kg} / \mathrm{mx} 9.81=1.72 \mathrm{kN} / \mathrm{m}$

as face load. $\delta=\frac{5 \mathrm{WL}^{4}}{384 \mathrm{EI}}=54 \mathrm{~mm}$ (tolerance overlap.

(ii) Global Response - Propose steel wire rope as supplementary bracing, with stiffness matched to semi-rigid frame, and with period approximately 3 times the local response, i.e. nominate $T=2.0$ sec for initial assessment.

Assume $70 \%$ of total stored mass as seismic live load.

$=0.70 \times 2$ No. $\times 9000 \mathrm{~kg} \times 9.81 \mathrm{~m} / \mathrm{sec}^{2}$

$=123.6 \mathrm{kN}$ per bay

$=2472 \mathrm{kN}$ for 20 No. bays.

Assuming an inverted triangular distribution of seismic load, equivalent mass at diaphragm level is:

$\mathrm{w}_{\mathrm{t}}=\frac{2}{3} \times 2472 \mathrm{kN}=1648 \mathrm{kN}$

Total base Shear from NZS 4203

Cl. 3.4.2 (with $\mathrm{S}=2.5$ for

damping in semi-rigid anchor frame) .

$C_{d}=\operatorname{CISMR}=0.0825 \times 0.7 \times 2.5$ $\times 0.8 \times 1.0=0.1155$ 


$$
\mathrm{V}=\mathrm{C}_{\mathrm{d}} \mathrm{W}_{\mathrm{t}}=190.3 \mathrm{kN}
$$

Nominate 4No. $19 \mathrm{~mm}$ dia. Fibre Core Steel ropes (UTS $=210 \mathrm{kN}$ per guy) with double back plan length 40 metres each.

Bracing horizontal stiffness $k=\frac{A E}{L}=\frac{4 \mathrm{No} \cdot \times 283 \mathrm{~mm}^{2} \times 63 \mathrm{kN} / \mathrm{mm}^{2}}{40 \times 10^{3}}$

Period $T=2 \tau \tau \sqrt{\overline{\mathrm{K}}}=2 \tau \tau \sqrt{\frac{1.67992 \mathrm{~kg}}{1.78 \times 10^{6}}}$

$=1.93 \mathrm{sec}$.

Check strength margin for design earthquake, indluding allowance for $\mathrm{p}-\delta$ effects.

- Seismic Shear: $\quad \delta_{1}=\frac{190.3 \mathrm{kN}}{1.78 \mathrm{kN} / \mathrm{mm}}=107 \mathrm{~mm}$,

$\left(\mathrm{V}_{1}=190.3 \mathrm{kN}\right)$
- P- $\delta$ Shear: $\Delta \mathrm{V}_{1}=1648^{\mathrm{kN}} \times \frac{107}{7000 \mathrm{~mm}}=24.9 \mathrm{kN}$

$\frac{24.9^{\mathrm{kN}}}{190.3 \mathrm{kN}}=0.131, \mathrm{P}-\delta$ Magnifier $=\frac{1}{(1-0.131)}$

$$
=1.15
$$

$\therefore \mathrm{V}_{1}+\Delta \mathrm{v}_{1}^{\prime}=1.15 \times 190.3^{\mathrm{kN}}=218.9^{\mathrm{kN}}$

- Cable Relaxation (assume $0.25 \%$ of length)

$=100 \mathrm{~mm}$

$\mathrm{v}_{2}=1648 \mathrm{kN} \times \frac{100}{7000}=23.5^{\mathrm{kN}}$

Total bracing reaction required $\mathrm{V}=218.9^{\mathrm{kN}}$

$+23.5^{\mathrm{kN}}=242.2^{\mathrm{kN}}$

Expected deformation $=1.15 \times 107 \mathrm{~mm}=123 \mathrm{~mm}$ plus $100 \mathrm{~mm}=223 \mathrm{~mm}(0.032 \mathrm{H})$.

Design load in guys (assume $45^{\circ}$ slope)

$=\sqrt{2} \times 242.4 \mathrm{kN}=343 \mathrm{kN}$

Strength margin available $=\frac{4 \mathrm{No} \cdot \mathrm{x} 210 \mathrm{kN}}{343 \mathrm{kN}}=2.45$

Sensitivity check possible amplified response in severe earthquake (assume $\mathrm{T}=1.5 \mathrm{sec}, \mathrm{A}_{\mathrm{r}}=3.0, \quad I=0.7$ )

Required strength margin $=\frac{0.7 \times 0.0825 \times 3.0}{0.1155}$

$$
=1.50(61 \%)
$$

Expected maximum deformation $=(1.50 \times 123 \mathrm{~mm})$

$+100 \mathrm{~mm}=285 \mathrm{~mm}(0.04 \mathrm{lH})$.

Design base anchorages and connections

for amplified response. Allow margin

$100 \mathrm{~mm}$ over predicted maximum deformation

for end clearance to building fabric

i.e. say $400 \mathrm{~mm}$ set back each end. 